University of Nebraska - Lincoln

DigitalCommons@University of Nebraska - Lincoln

Mammalogy Papers: University of Nebraska

State Museum

Museum, University of Nebraska State

2-1-1971

\title{
Morphological Variation in Stenoderma rufum
}

J, Knox Jones Jr.

The University of Kansas, Lawrence

Hugh H. Genoways

The University of Kansas, Lawrence, h.h.genoways@gmail.com

Robert J. Baker

Texas Tech University, rjbaker@ttu.edu

Follow this and additional works at: https://digitalcommons.unl.edu/museummammalogy

Part of the Biodiversity Commons, Ecology and Evolutionary Biology Commons, and the Zoology

Commons

Knox Jones, J, Jr.; Genoways, Hugh H.; and Baker, Robert J., "Morphological Variation in Stenoderma rufum" (1971). Mammalogy Papers: University of Nebraska State Museum. 45.

https://digitalcommons.unl.edu/museummammalogy/45

This Article is brought to you for free and open access by the Museum, University of Nebraska State at DigitalCommons@University of Nebraska - Lincoln. It has been accepted for inclusion in Mammalogy Papers: University of Nebraska State Museum by an authorized administrator of DigitalCommons@University of Nebraska Lincoln. 


\section{MORPHOLOGICAL VARIATION IN STENODERMA RUFUM}

For more than 100 years, the red fruit-eating bat, Stenoderma rufum Desmarest, 1820, was known only by a specimen of unknown geographic provenience. Anthony $(1918,1925)$ rediscovered Stenoderma in Puerto Rican cave deposits, but the first living specimens to be reported since the original description were taken on St. John in the Virgin Islands (Hall and Bee, 1960). Subsequently, Tamsitt and Valdivieso (1966) recorded living representatives from Puerto Rico-from a population later named and described as a distinctive subspecies, Stenoderma rufum darioi, by Hall and Tamsitt (1968). The latter authors also reported a specimen of S. r. rufum from St. Thomas. Choate and Birney (1968), based on their study of Recent and sub-fossil material, named and described a third subspecies, Stenoderma rufum anthonyi, from cave deposits in Puerto Rico. The only other recent references in the literature to Stenoderma are those of Tamsitt and Fox (1970), who recorded a listrophorid mite from a specimen from Puerto Rico, and two papers on electrophoretic properties of hemoglobin (Valdivieso et al., 1969, and Tamsitt and Valdivieso, 1969); S. rufum remains one of the least known of North American phyllostomatids. In the period 17-20 July 1969, one of us (Baker) took 28 specimens, 17 males and 11 females (housed in the collections at Texas Tech University, TT 8858-84, 9830), in mist nets set near the El Verde Research Station, Laquillo National Forest, Puerto Rico. These, along with a male and female in the Museum of Natural History at The University of Kansas (KU 114009-10) from the same place that were earlier reported by Hall and Tamsitt (op. cit.), form the basis for the present report on variation in S. rufum from that island. Also, we have used in our comparisons two of the three specimens from St. John (KU 74030-31) reported by Hall and Bee (op. cit.) as well as the holotype of S. $r$. anthonyi.

At the El Verde Research Station, red fig-eating bats were taken in nets set in tropical broad-leaf forest and above the forest canopy. In the latter situation, a 30-foot net was stretched between two towers above the dense canopy. Two Stenoderma, two Brachyphylla cavernarum, and four Artibeus jamaicensis were taken in this net. Other species of bats netted within the forest along with Stenoderma included Pteronotus parnellii, Monophyllus redmani, Erophylla bombifrons, Eptesicus fuscus, and Molossus molossus. Of the adult females of S. rufum preserved, one of six was lactating but the others showed no gross reproductive activity. However, six females that were pregnant when captured (the embryo in each appeared near term) were banded and released. One gave birth about an hour after capture; the neonate immediately attached to a teat and was carried easily by the female when she was later released.

Secondary sexual variation is marked in our Puerto Rican samples. Males average smaller than females in every measurement analyzed (Table 1), significantly so at the .05 level in two and at the .01 level in eight (forearm and seven cranial dimensions). Choate and Birney (1968:409) suggested, on the basis of evidence from subfossil material, that sexual dimorphism occurred in Stenoderma, as implied also by the measurements listed by Hall and Tamsitt (1968:3). The female of S. r. rufum from St. John is considerably smaller than females from Puerto Rico, being even slightly smaller in some measurements (Table 1) than the male from St. John. The latter does not differ in size from Puerto Rican males. Sexual dimorphism of the magnitude seen in the Puerto Rican population has been reported also for the related Antillean genus Ardops: (Jones and Schwartz, 1967:4).

The measurements of immature specimens (those with a grayish pelage and unfused or incompletely fused phalangeal epiphyses) are not included in Table 1 because their crania, although nearly of adult size, were significantly smaller statistically in some dimensions. Additionally, the forearms of immature males were significantly shorter than those of adults.

Color of the dorsum in our Puerto Rican series varies from tan to a dark chocolate brown. The darkest individuals appear to be those that only recently completed molt from juvenile to adult pelage. Two of our specimens are noticeably paler than others from 


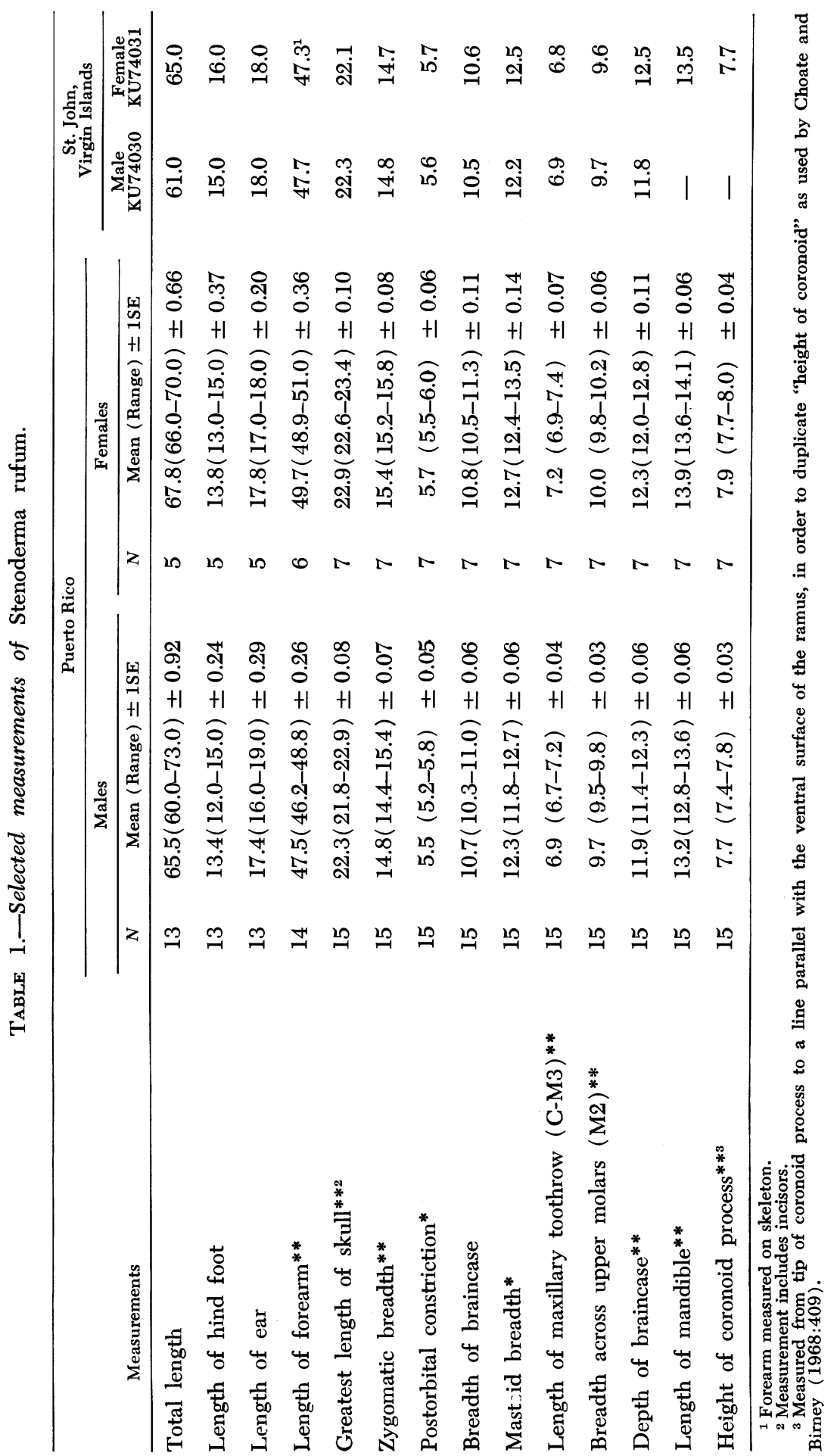


TABLE 2.-Dorsal color reflectance values for adults of Stenoderma rufum from Puerto Rico (average, extremes, and one standard error for 19 specimens) and two specimens from St. John, the Virgin Islands. Readings were taken in the middorsal region with a Photovolt Photoelectric Reflectance Meter (Model 610).

\begin{tabular}{lrr}
\hline Color & Puerto Rico & \multicolumn{1}{c}{ St. John } \\
\hline Red & $16.5(11.5-23.5) \pm 0.68$ & $25.5,27.5$ \\
Green & $7.1(4.5-10.5) \pm 0.32$ & $12.5,14.0$ \\
Blue & $5.9(4.0-10.5) \pm 0.33$ & $9.0,10.5$ \\
\hline
\end{tabular}

Puerto Rico and approach August-taken S. r. rufum in color (the latter described as Buckthorn Brown dorsally by Hall and Tamsitt, 1968:3). Reflectance readings of the dorsal color in S. $r$. darioi and S. $r$. rufum are given in Table 2; the upper readings in each instance for darioi are those of the palest of the two specimens mentioned above. Six Puerto Rican specimens (three males and three females) are in juvenile pelage, which is grayer than adult pelage and is fuzzy in appearance. All specimens, adults and juveniles, are noticeably darker ventrally than dorsally, and all have the characteristic white spots on the side of the neck and at the dorso-anterior base of the wing.

Of the 30 specimens studied from Puerto Rico, all but one had the complete dental complement for the genus, and none revealed dental caries or loss of teeth in life. A female (KU 114009) lacked the minute and peglike third lower molar on both sides. The describers of S. r. anthonyi (Choate and Birney, 1968:407-408) claimed for that subfossil race a "more or less pronounced accessory cusplet on the posteriointernal surface of the entoconid of the first lower molar," which was larger than that in any Recent specimens examined by them. Comparison of our Puerto Rican material with the holotype of anthonyi reveals that this cusplet is, indeed, larger in anthonyi than in darioi, but rarely proportionately so, inasmuch as the teeth of anthonyi are the larger overall. We also noted that the labial cingula of the first two lower molars of anthonyi are much better developed than in darioi and support more prominent cingular cusps.

All phyllostomatid bats thus far examined lack a baculum (Jones and Genoways, 1970), and it was not surprising, therefore, to find that Stenoderma rufum (three males examined) also lacks this bone. Chromosomes of S. rufum will be discussed elsewhere.

In summary, Stenoderma rufum is a polytypic species that is represented in Puerto Rico by S. $r$. darioi, a population characterized both by marked secondary sexual dimorphism and by darker color than in the other Recent race, S. r. rufum from the Virgin Islands. The subfossil S. $r$. anthonyi from Puerto Rico is much larger than darioi and differs from it also in several dental details.

We thank Dr. George Drewry of the Puerto Rico Nuclear Center for use of facilities there and for his assistance during our stay. Genaro Lopez aided in collection of specimens. Field work was supported by a grant (GB-8120) from the National Science Foundation.

\section{Literature Cited}

Anthony, H. E. 1918. The indigenous land mammals from Porto Rico, living and extinct. Mem. Amer. Mus. Nat. Hist., n. s., 2: 331-435.

1925. Mammals of Porto Rico, living and extinct-Chiroptera and Insectivora. Scientific Survey of Porto Rico and the Virgin Islands, New York Acad. Sci., 9: 1-96.

Chonte, J. R., and E. C. Birney. 1968. Sub-Recent Insectivora and Chiroptera from Puerto Rico, with the description of a new bat of the genus Stenoderma. J. Mamm., 49: 400-412. 
Hall, E. R., AND J. W. BEe. 1960. The red fig-eating bat Stenoderma rufum Desmarest found alive in the West Indies. Mammalia, 24: 67-75.

Hall, E. R., and J. R. Tamsitr. 1968. A new subspecies of the red fig-eating bat from Puerto Rico. Life Sci. Occas. Papers, Royal Ontario Mus., 11: 1-5.

Jones, J. K., Jr., And H. H. Genoways. 1970. Chiropteran systematics. J. Grad. Res. Center, Southern Methodist Univ., in press.

Jones, J. K., Jr., AND A. Schwartz. 1967. Bredin-Archbold-Smithsonian biological survey of Dominica. 6. Synopsis of bats of the Antillean genus Ardops. Proc. U. S. Nat. Mus., 124(3634): 1-13.

TAmsitt, J. R., And I. Fox. 1970. Mites of the family Listrophoridae in Puerto Rico. Canadian J. Zool., 48: 398-399.

TAmsitt, J. R., AND D. Valdivieso. 1966. Parturition in the red fig-eating bat, Stenoderma rufum. J. Mamm., 47: 352-353.

1969. Hemoglobin electrophoresis in systematics of bats (Microchiroptera). Life Sci. Occas. Papers, Royal Ontario Mus., 14: 1-12.

Valdivieso, D., J. R. Tamsitt, and E. Conde-del Pino. 1969. Electrophoretic properties of Neotropical bat hemoglobin. Comp. Biochem. Physiol., 30: 117-122.

J. Knox Jones, Jr., Hugh H. Genoways, And Robert J. Baker, Museum of Natural History, The University of Kansas, Lawrence, 66044, and Department of Biology, Texas Tech University, Lubbock, 79409. Accepted 24 November 1970. 